\title{
Kajian Pengaruh Angin Musim Terhadap Sebaran Suhu Permukaan Laut (Studi Kasus : Perairan Pangandaran Jawa Barat)
}

\author{
Azis Rifai $^{{ }^{*} \text {, Baskoro Rochaddi }}{ }^{1}$, Ulha Fadika ${ }^{2}$, Jarot Marwoto $^{1}$, Heryoso Setiyono ${ }^{1}$ \\ ${ }^{I}$ Departemen Oseanografi, Fakultas Perikanan dan Ilmu Kelautan \\ ${ }^{2}$ Program Sarjana Departemen Oseanografi, Fakultas Perikanan dan Ilmu Kelautan \\ Jl. Prof. H. Soedharto, SH Tembalang Semarang 50239 Telp. 024-7460044 \\ Email:*papahrifa@yahoo.com
}

\begin{abstract}
Abstrak
Perairan Pangandaran merupakan bagian dari samudera Indonesia dan mendapat pengaruh sistem angin musim. Dinamika arah dan kecepatan angin musim berpengaruh terhadap dinamika arus permukaan di perairan Pangandaran. Pergerakan arus permukaan berpengaruh terhadap sebaran suhu permukaan laut perairan Pangandaran. Tujuan penelitian adalah untuk mengetahui perubahan arah dan kecepatan angin musim dan kaitannya terhadap sebaran suhu permukaan laut di perairan Pangandaran. Penelitian ini dilaksanakan pada bulan Agustus 2013. Penelitian menggunakan metode kuantitatif. Analisa statistik digunakan untuk mengetahui nilai error suhu permukaan laut yang didapat berdasar citra MODIS. Berdasarkan hasil penelitian diketahui bahwa pada musim Barat angin dominan bertiup dari arah Barat Daya menuju ke Timur Laut dengan kecepatan 5,7 8,8 knot, sedangkan arus permukaan bergerak ke Timur dengan kecepatan rata - rata 0,4 knot. Pada musim Timur angin dominan bertiup dari arah Timur menuju Barat dengan kecepatan 8,8-11,1 kno,t sedangkan arus permukaan bergerak ke Barat Laut dengan kecepatan rata - rata 0,18 knot. Sedangkan pada musim Peralihan tidak menunjukkan pengaruh arah dan kecepatan angin terhadap arah arus permukaan. Pada musim Peralihan didapatkan suhu permukaan laut yang maximum yaitu $31,7^{\circ} \mathrm{C}$ dan minimum yaitu $25,4^{\circ} \mathrm{C}$ sepanjang tahun.
\end{abstract}

Kata kunci : Perairan Pangandaran, Angin, Arus, Suhu Permukaan Laut

\section{Abstract}

Pangandaran waters is a part of the Indonesian ocean and are affected by the monsoon system. The dynamics of the direction and speed of monsoons affect the dynamics of surface currents in Pangandaran waters. The flow of surface currents affects the distribution of sea surface temperature in Pangandaran waters. The purpose of this study was to determine the dynamics of direction and speed of monsoon winds and their relationship to the distribution of sea surface temperatures in Pangandaran waters. This research was conducted in August 2013. The research used quantitative methods. Statistical analysis wss used to determine the error of sea surface temperature obtained from the MODIS image. The results of the study showed that in the West monsoon the dominant wind blows from the Southwest toward the Northeast with speeds of $5.7-8.8$ knots, while surface currents flow to the Eastward with an average speed of 0.4 knots. In the East monsoon the dominant wind blows from East to West with a speed of 8.8 - 11.1 knot, while surface currents flow to the Northwestward with an average speed of 0.18 knots. Whereas in the Transition monsoon did not show the influence of wind direction and speed on the direction of surface currents. During the Transition monsoon, the maximum sea surface temperature is $31.7^{\circ} \mathrm{C}$ and the minimum is $25.4^{\circ} \mathrm{C}$ throughout the year.

Keywords : Southern Pangandaran, Wind, Current, Sea Surface Temperature

\section{Pendahuluan}

Gerak semu matahari menyebabkan perbedaan tekanan udara di belahan bumi utara (BBU) dan belehan bumi selatan (BBS). Indonesia yang berada pada garis katulistiwa merupakan daerah lintasan pergerakan udara sebagai akibat dari perbedaan tekanan udara pada kedua belahan bumi ini. Pergerakan udara ini dikenal sebagai angin muson. Angin muson secara bergantian bergerak melintasi wilayah Indonesia sepanjang tahun dengan periode enam bulan yakni bulan April hingga September (angin muson timur) dan Oktober hingga Maret (angin muson barat) (Dida et al.2016).

Perairan Pangandaran merupakan salah satu perairan yang dipengaruhi oleh sistem angin muson. Sistem angin muson ini berpengaruh terhadap fluktuasi karakteristik perairan seperti angin, 
arus, serta sebaran suhu. McPhaden dan Hayes (1991) menyatakan bahwa pergerakan angin akan mempengaruhi karakteristik massa air di laut, salah satunya adalah terjadinya perubahan arah arus permukaan. Pergerakan angin yang kuat pada permukaan air mempengaruhi terjadinya percampuran massa air pada lapisan atas dan menjadikan sebaran suhu homogen.

Berdasarkan penelitian Putra (2004) diketahui bahwa pada saat Musim Timur, di perairan selatan Jawa bertiup angin dari benua Australia menuju ke arah Barat. Hal ini menyebabkan pergerakan massa air permukaan dari selatan pulau Jawa menuju barat samudera Indonesia. Pergerakan massa air permukaan ini menyebabkan sirkulasi massa air dari bagian dalam yang bersuhu rendah, naik ke atas menggantikan massa air permukaan yang berpindah.

Tujuan dari penelitian ini adalah untuk mengetahui dinamika arah dan kecepatan angin musim di perairan Pangandaran Jawa Barat serta mengetahui mengetahui perubahan arus permukaan perairan dan kaitannya dengan sebaran suhu permukaan laut di perairan Pangandaran Jawa Barat.

\section{Materi dan Metode}

Penelitian dilaksanakan di perairan Pangandaran. Penelitian ini menggunakan data primer berupa nilai suhu permukaan laut (SPL) yang diukur secara insitu pada bulan Agustus 2013. Selanjutnya data ini digunakan sebagai verifikasi data SPL citra. Data sekunder penelitian berupa data arah dan kecepatan angin, data model arus permukaan, serta data SPL citra MODIS Terra level 3 bulanan tahun 2013.

Metode yang digunakan dalam analisa data penelitian adalah metode kuantitatif. Sedangkan analisa data secara statistik digunakan untuk menentukan nilai error dari data SPL citra MODIS.

\section{a. Metode Pengambilan Data \\ Data Citra MODIS}

Citra MODIS yang digunakan adalah citra Terra MODIS level 3 dengan resolusi $4 \mathrm{~km}$, setiap bulan selama tahun 2013. Data Citra Terra MODIS ini yang diperoleh dari situs NASA (http://oceancolor.gsfc.nasa.gov).

\section{Data SPL Insitu Sebagai Verifikasi Data Citra}

Pengambilan data SPL lapangan dilakukan di perairan Pangandaran Jawa Barat pada 12 titik sampling. Data SPL diukur menggunakan digital pocket termometer dengan pengulangan sebanyak tiga kali.

\section{Data Angin}

Data angin didapatkan dari Instansi Badan Meteorologi Klimatologi dan Geofisika Stasiun Meteorologi Cilacap Jawa Tengah. Data angin berupa titik koordinat, arah, dan kecepatan angin yang bertiup di perairan Pangandaran selama tahun 2013.

\section{Arus Permukaan}

Data arus permukaan didapatkan dari Instansi Badan Meteorologi Klimatologi dan Geofisika Stasiun Meteorologi Cilacap Jawa Tengah. Data arus merupakan hasil pemodelan arus permukaan berdasarkan data arah dan kecepatan angin yang bertiup di perairan Pangandaran.

\section{b. Metode Pengolahan dan Analisis Data \\ Metode Pengolahan data Angin}

Pengolahan data angin dengan menggunakan software WRPLOT View mendapatkan output arah dan kecepatan angin dominan permusim di wilayah perairan Pangandaran. Pengolahan data angin dengan menggunakan software ArcGIS 9.3 mendapatkan output berupa vektor angin di wilayah perairan Pangandaran.

\section{Metode Pengolahan Data Arus Permukaan}

Data arah dan kecepatan arus permukaan divisualisasi menggunakan software ArcGIS 9.3. Data visual ini digunakan untuk melihat perubahan arus permukaan setiap musimnya.

\section{Metode pengolahan data SPL citra Terra MODIS}

Data SPL didapatkan dari satelit Terra MODIS. Analisa data suhu permukaan laut menggunakan software ENVI 5.0, Microsoft Excel 2010 dan ArcGis 9.3. 


\section{a. Analisis Verifikasi Data Citra dengan Data Lapangan}

Verifikasi data dilakukan untuk mengetahui kesesuaian antara data suhu permukaan laut berdasarkan nilai rekaman citra satelit Terra MODIS dengan data suhu permukaan laut yang diambil secara insitu.

Menurut Triatmodjo (2010) verifikasi data dilakukan dengan menghitung nilai mean relative error (MRE). Koreksi kesalahan relatif dapat dihitung dengan cara :

$$
\begin{aligned}
& R E=\left[\frac{X-C}{X}\right] x 100 \% \\
& M R E=\frac{\sum_{1}^{n} R E}{n}
\end{aligned}
$$

Keterangan :

RE : kesalahan relatif (Relative Error)

MRE : rata-rata kesalahan relatif (Mean Relative Error)

$\mathrm{X} \quad$ : data SPL hasil pengukuran di lapangan

C : data SPL citra

$\mathrm{n} \quad$ : jumlah data

\section{b. Analisis Data SPL dengan Data Arus Permukaan}

Analisis data sebaran suhu permukaan laut dan data arus permukaan dilakukan untuk mengetahui kaitan sebaran suhu permukaan laut dengan kondisi arus permukaan di perairan Pangandaran Jawa Barat. Hasil analisa disajikan dalam bentuk overlay peta sebaran suhu permukaan laut dan arah arus permukaan.

\section{Hasil dan Pembahasan}

\section{a. Data Angin}

Data angin dari instansi Badan Meteorologi Klimatologi dan Geofisika (BMKG) Cilacap berupa data arah dan kecepatan angin. Analisa data dengan Software WRPLOT View memperlihatkan arah angin yang dominan setiap musimnya.

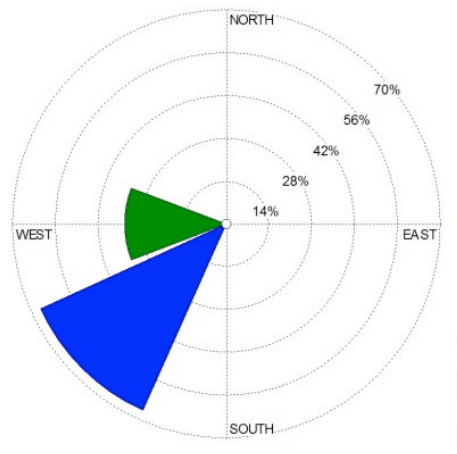

a. Musim Barat

(Desember - Februari)
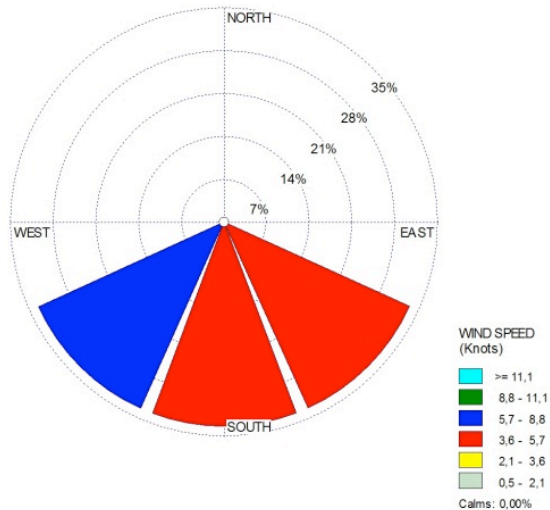

b. Musim Peralihan I

(Februari - Mei) 


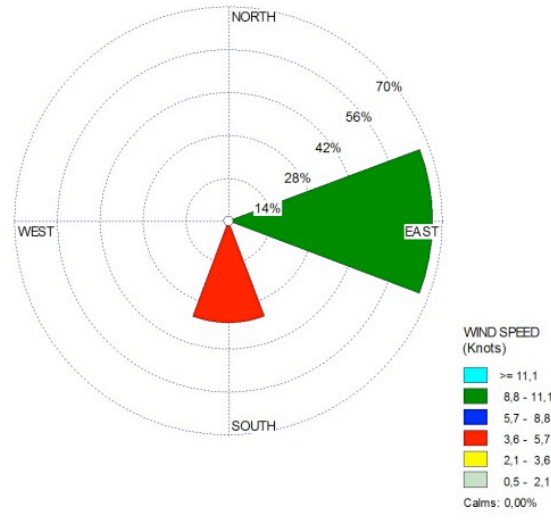

c. Musim Timur

(Juni - Agustus)

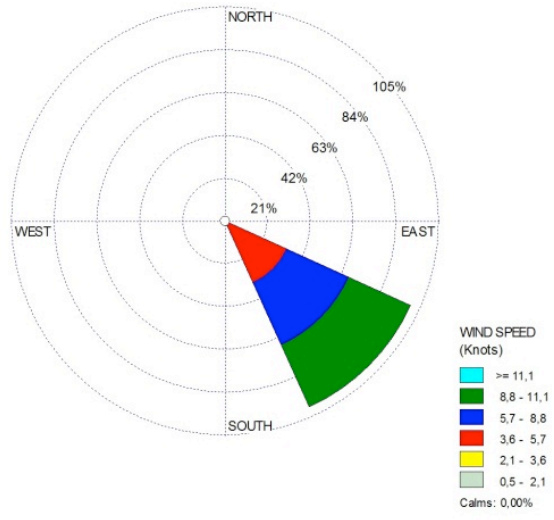

d. Musim Peralihan II

(September - November)

Gambar 1. Windrose Permusim Tahun 2013

Gambar 1 menunjukan arah angin pada setiap fase musim tahun 2013. Pada musim Barat (a) angin dominan dari arah Barat Daya dengan kecepatan 5,7 - 8,8 knot. Pada musim Peralihan I (b) angin berhembus dari tiga arah, yaitu Tenggara, Selatan, dan Barat Daya, dengan kecepatan angin 2,6 - 5,7 knot. Pada musim Timur (c) angin dominan dari arah Timur, dengan kecepatan 8,8-11,1 knot. Sedangkan pada musim Peralihan II (d) angin dominan dari arah Tenggara dengan kecepatan 2,6 11,1 knot.

Analisa data angin dengan software ArcGIS 9.3, didapatkan output berupa vektor angin yang bertiup di atas perairan Pangandaran.

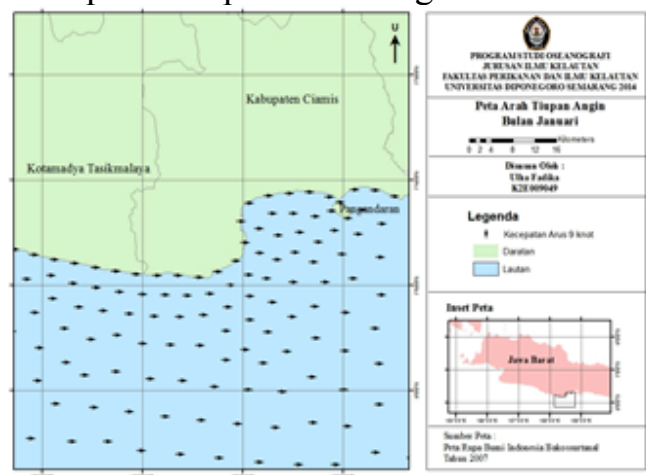

Gambar 2. Peta Arah Tiupan Angin Pada Musim Barat

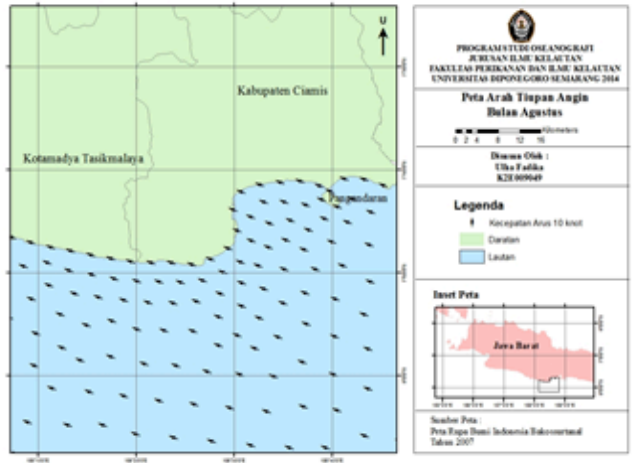

Gambar 4. Peta Arah Tiupan Angin Pada Musim Timur

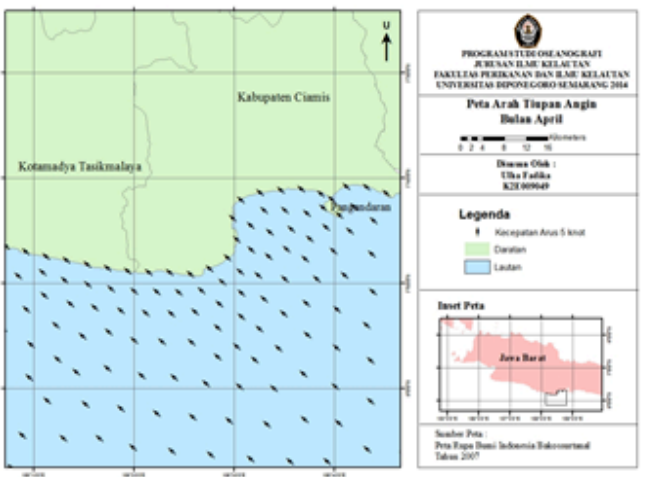

Gambar 3. Peta Arah Tiupan Angin Pada Musim Peralihan I

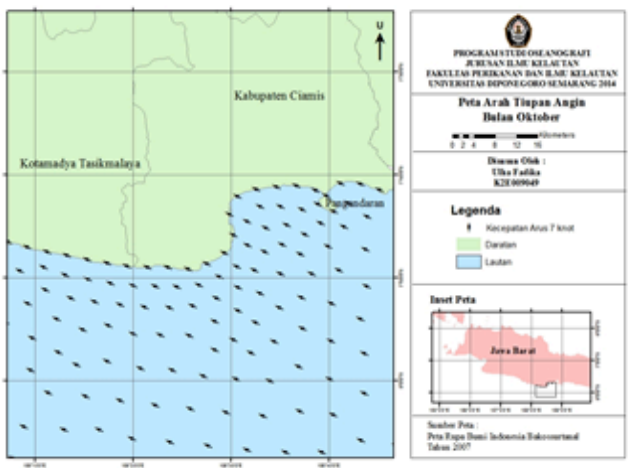

Gambar 5. Peta Arah Tiupan Angin Pada Musim Peralihan II knot. Pada musim Peralihan I (bulan April), angin bertiup ke arah Barat Laut dengan kecepatan rata rata 5 knot. Pada musim Timur yang (bulan Agustus), angin bertiup ke arah Barat dengan kecepatan rata - rata 10 knot. Pada musim Peralihan II (bulan Oktober), angin bertiup ke arah Barat Laut dengan kecepatan rata - rata 7 knot. 


\section{b. Data Arus Permukaan}

Data arah dan kecepatan arus permukaan didapatkan dari instansi Badan Meteorologi Klimatologi dan Geofisika Stasiun Meteorologi Cilacap.

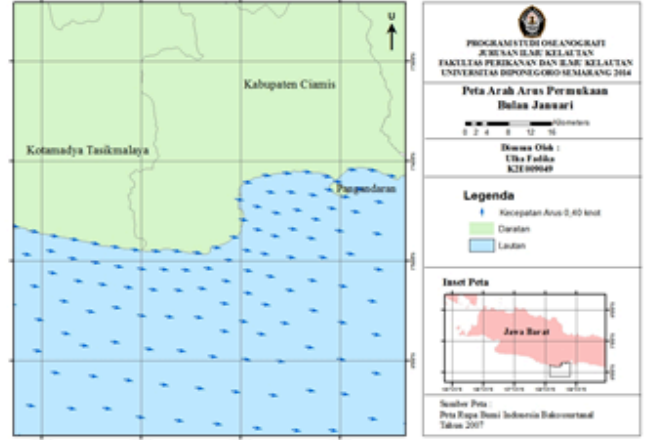

Gambar 6. Peta Arus Permukaan Musim Barat

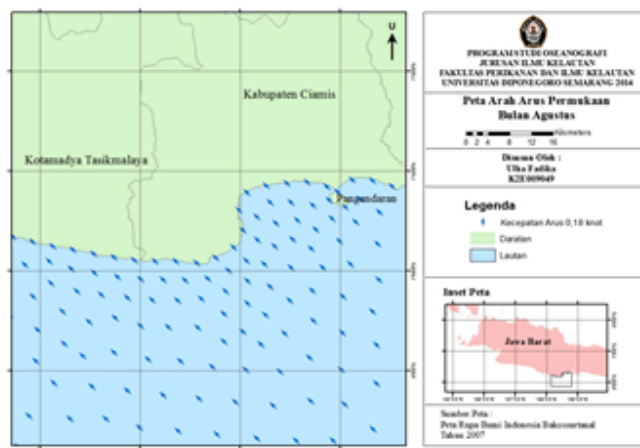

Gambar 8. Peta Arus Permukaan Musim Timur

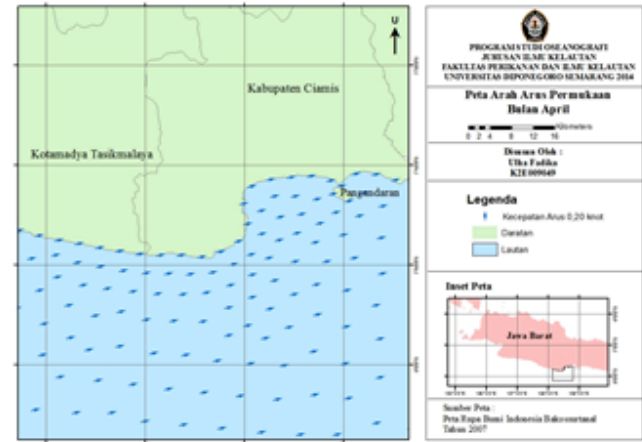

Gambar 7. Peta Arus Permukaan Musim Peralihan I

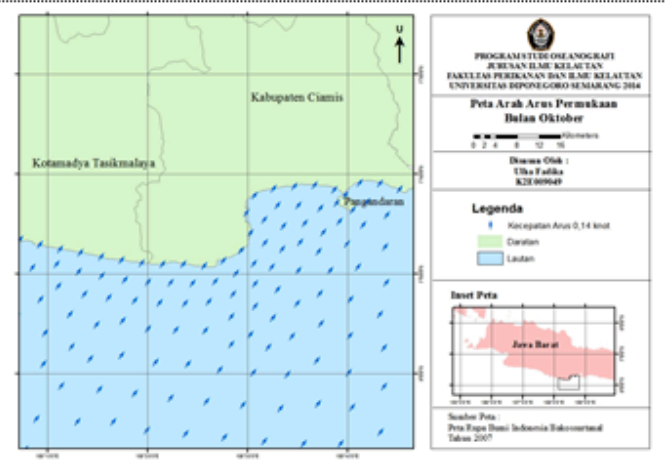

Gambar 9. Peta Arus Permukaan Peralihan II

Analisa data arus dengan software ArcGIS 9.3 didapatkan vektor arus setiap fase musim. Arus permukaan menunjukkan perubahan arah setiap pergantian musim. Pada musim Barat arus permukaan bergerak menuju arah Timur dengan kecepatan 0,40 knot. Pada musim Peralihan I arus permukaan bergerak menuju arah Timur dengan kecepatan 0,20 knot. Memasuki musim Timur arus permukaan berubah arah menuju kearah Barat Laut dengan kecepatan 0,18 knot. Sedangkan untuk musim Peralihan II arus permukaan bergerak menuju arah Timur Laut dengan kecepatan 0,14 knot.

\section{c. Data Suhu Permukaan laut}

Data suhu permukaan laut (SPL) perairan Pangandaran didapatkan berdasarkan data SPL citra MODIS. Data SPL citra tersebut diverifikasi dengan data SPL hasil pengukuran dilapangan. Hasil verifikasi ditinjukan pada tabel berikut :

Tabel 1. Tabel Perbandingan Suhu insitu dan Suhu dari Citra

\begin{tabular}{|c|c|c|c|c|c|c|c|c|c|}
\hline \multirow[b]{2}{*}{ No } & \multicolumn{2}{|c|}{ Koordinat } & \multicolumn{3}{|c|}{ Suhu Insitu } & \multirow{2}{*}{$\begin{array}{l}\text { Rata } \\
\text { Rata } \\
\text { SPL }\end{array}$} & \multirow{2}{*}{$\begin{array}{l}\text { Rata } \\
\text { Rata } \\
\text { Pixel }\end{array}$} & \multirow{2}{*}{$\begin{array}{l}\text { SPL } \\
\text { Citra }\end{array}$} & \multirow[b]{2}{*}{ error } \\
\hline & $\begin{array}{c}\text { Lintan } \\
\mathrm{g}\end{array}$ & Bujur & 1 & 2 & 3 & & & & \\
\hline 2 & $\begin{array}{l}-7,708 \\
-7,700\end{array}$ & $\begin{array}{c}108,67 \\
3 \\
108,67 \\
9\end{array}$ & $\begin{array}{c}28 \\
28,4\end{array}$ & $\begin{array}{l}27,5 \\
27,6\end{array}$ & $\begin{array}{l}27,3 \\
27,5\end{array}$ & $\begin{array}{l}27,6 \\
27,8\end{array}$ & 27,7 & 27,9 & $0,66 \%$ \\
\hline 4 & $\begin{array}{l}-7,711 \\
-7,701\end{array}$ & $\begin{array}{c}108,68 \\
4 \\
108,68 \\
7\end{array}$ & 27,5 & 27,3 & 27,3 & $\begin{array}{l}27,4 \\
27,4\end{array}$ & 27,4 & 28,0 & $2,15 \%$ \\
\hline
\end{tabular}




\begin{tabular}{|c|c|c|c|c|c|c|c|c|c|}
\hline 5 & $-7,705$ & $\begin{array}{c}108,69 \\
2\end{array}$ & 27,7 & 27,4 & 27,3 & 27,5 & & & \\
\hline 6 & $-7,714$ & $\begin{array}{c}108,69 \\
3\end{array}$ & 27,6 & 27,5 & 27,3 & 27,5 & & & \\
\hline 7 & $-7,725$ & $\begin{array}{c}108,69 \\
3\end{array}$ & 27,8 & 27,7 & 27,5 & 27,7 & 27,6 & 28,1 & $1,81 \%$ \\
\hline 8 & $-7,732$ & $\begin{array}{c}108,68 \\
2\end{array}$ & 27,9 & 27,6 & 27,5 & 27,7 & & & \\
\hline 9 & $-7,734$ & $\begin{array}{c}108,66 \\
2\end{array}$ & 27,9 & 27,7 & 27,5 & 27,7 & 27,7 & 28,0 & $1,08 \%$ \\
\hline 10 & $-7,716$ & $\begin{array}{c}108,64 \\
2\end{array}$ & 27,6 & 27,5 & 27,4 & 27,5 & 27,5 & 27,8 & $1,09 \%$ \\
\hline 11 & $-7,710$ & $\begin{array}{c}108,63 \\
3\end{array}$ & 27,7 & 27,6 & 27,5 & 27,6 & 275 & 277 & $067 \%$ \\
\hline 12 & $-7,705$ & $\begin{array}{c}108,62 \\
0 \\
\end{array}$ & 27,5 & 27,4 & 27,4 & 27,4 & & & \\
\hline \multicolumn{9}{|c|}{ Jumlah } & $7,46 \%$ \\
\hline & & & & & & & & MRE & $1,24 \%$ \\
\hline
\end{tabular}

Hasil verifikasi menunjukan nilai koreksi kesalahan relatif dengan rata - rata presentase kesalahan 1,24\%. Dari nilai koreksi kesalahan relatif tersebut dapat disimpulkan bahwa data SPL citra satelit Terra MODIS dapat digunakan untuk mengetahui persebaran suhu permukaan laut di perairan Pangandaran.

Visualisasikan data SPL citra menggunakan software ArcGIS 9.3. didapatkan data sebaran SPL perairan Pangandaran untuk setiap fase musim.

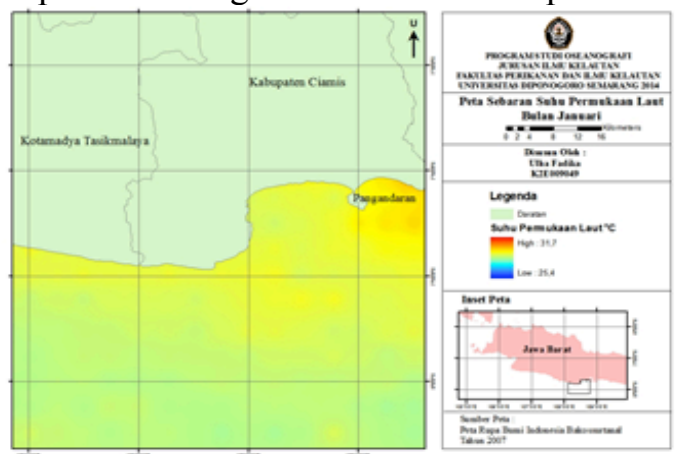

Gambar 10. Peta Sebaran SPL Musim Barat

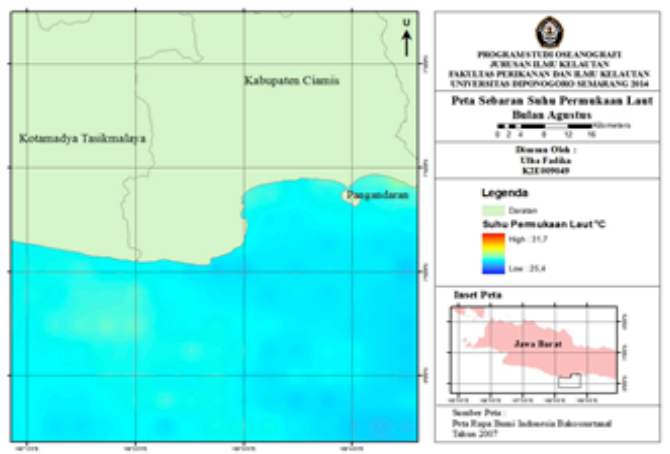

Gambar 12. Peta Sebaran SPL Musim Timur

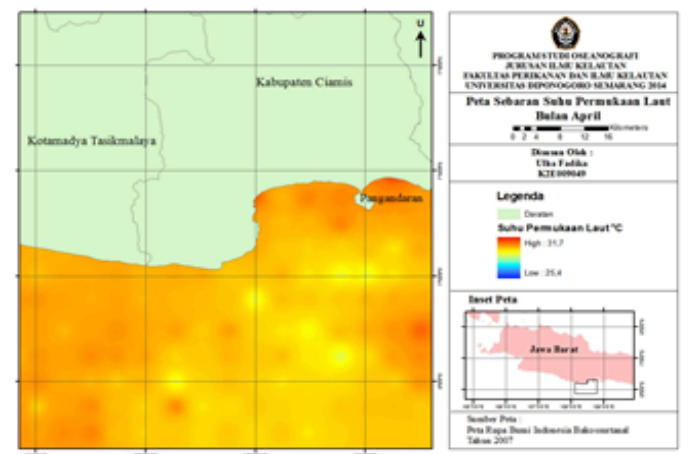

Gambar 11. Peta Sebaran SPL Musim Peralihan I

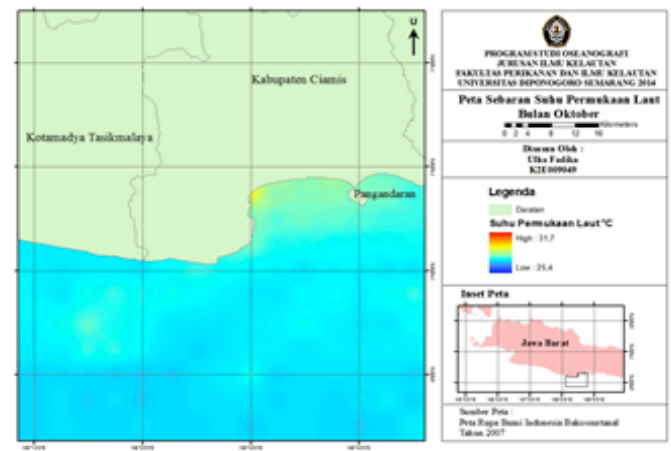

Gambar 13| Peta Sebaran SPL Musim Peralihan II

Sebaran SPL di perairan Pangandaran menunjukkan perbedaan pada setiap fase musim. Pada musim Peralihan I, sebaran SPL menunjukkan rata-rata yang lebih tinggi yaitu minimum $29,2^{\circ} \mathrm{C}$ dan nilai maximum $31,7^{\circ} \mathrm{C}$. Sedangkan pada musim Peralihan II sebaran SPL menunjukkan rata-rata yang lebih rendah yaitu minimum $25,4^{\circ} \mathrm{C}$ dan nilai maximum $31,1^{\circ} \mathrm{C}$. 


\section{d. Variabilitas Pergerakan Angin Permukaan}

Dari hasil analisa data arah dan kecepatan angin, menunjukkan bahwa angin di wilayah perairan Pangandaran mengalami perubahan arah dan kecepatan pada setiap fase musim. Pola perubahannya menunjukkan adanya kaitan dengan perubahan sistem angin musim. Hal ini menunjukkan bahwa perairan Pangandaran masih mendapatkan pengaruh dari sistem angin musim.

\section{e. Pengaruh Angin Terhadap Pergerakan Arus Permukaan}

Dari hasil analisa arah dan kecepatan arus permukaan di perairan Pangandaran, menunjukkan bahwa pada saat fase musim dengan angin dominan (musim Barat dan musim Timur), angin berpengaruh terhadap arah dan kecepatan arus permukaan di perairan Pangandaran. Sedangkan pada saat fase musim dengan angin tidak dominan, angin tidak berpengaruh terhadap arah dan kecepatan arus permukaan di perairan Pangandaran.

\section{f. Pengaruh Arus Permukaan Terhadap Sebaran Suhu Permukaan Laut}

Dari hasil analisa sebaran SPL di perairan Pangandaran, menunjukkan bahwa sebaran SPL dipengaruhi oleh perubahan arah dan kecepatan arus permukaan. Perubahan SPL tidak signifikan sesuai dengan perubahan araus permukaan, namun pola perubahaan SPL menunjukkan pola yang hampir sama dengan perubahan arus permukaan. Hal ini secara tidak langsung menunjukkan adanya kaitan antara perubahan sebaran SPL di perairan Pangandaran dengan perubahan angin musim yang bertiup di wilayah perairan Pangandaran.

\section{Kesimpulan dan Saran}

Perubahan arah dan kecepatan angin musiman di perairan Pangandaran berpengaruh terhadap perubahan arah dan kecepatan arus permukaan. Hal ini secara jelas terlihat pada musim Barat dan musim Timur. Sedangkan pada musim Peralihan, perubahan arah dan kecepatan angin tidak berpengaruh arus permukaan.

Sebaran suhu permukaan laut memiliki pola yang hampir sama dengan pola perubahan arus permukaan. Sehingga disimpulkan bahwa sebaran SPL di perairan Pangandaran memiliki kaitan dengan arus permukaan. Dengan demikian sebaran SPL di perairan Pangandaran berkaitan dengan perubahan angin musim di wilayah perairan Pangandaran.

\section{Daftar Pustaka}

Dida, Hero P. , Sudjito Suparman , Denny Widhiyanuriyawan. 2016. Pemetaan Potensi Energi Angin di Perairan Indonesia Berdasarkan Data Satelit QuikScat dan WindSa Jurnal Rekayasa Mesin Vol.7, No.2 Tahun 2016: 95-101. T.

Iskandar, I., M T Tozuka., H. Sasaki., Y. Masumoto and T. Yamagata. 2006. Intraseasonal Variations of Surface and Subsurface Current Off Java As Simulated in High - Resolution Ocean General Circulation Model. Geophys. Re., 111:15 pp.

McPhaden, and S. P. Hayes, 1991. On The Variability of Winds, Sea Surface Temperature, and Surface Layer Heat Content in The Western Wquatorial Pasific. J. Geosphys. Res. 96: 3331 3342.

Putra, E. 2004. Variabilitas Angin dan Paras Laut Serta Interaksina di Perairan Utara dan Selatan Pula Jawa. Bogor. Intitut Pertanian Bogor.

Susanto, D., A.L. Gordon, and Q. Zheng. 2001. Upwelling Along The Coast of Java and Sumatera and Its Relation to ENSO. Geophys. Res. Lett. 28(8):1599 -1602.

Triatmodjo, Bambang. 2010. Metode Numerik.Yogyakarta. Betta Offset.

Tubalawony, S., Kusmanto E., Muhadjirin. 2012. Suhu dan Salinitas Permukaan Merupakan Indikator Upwelling Sebagai. LIPI. Jakarta. Vol 17. 